\title{
Assessment of Challenges and Prospects of Entrepreneurial Attitude on Students: The Case of Wachemo University, Ethiopia
}

\author{
Endalkachew Desta Moloro \\ Department of Management, Wachemo University, Hosanna, Ethiopia, PO box 667 \\ Zemede Chamiso Haile \\ Department of Economics, Wachemo University, Hosanna, Ethiopia, PO box 667
}

\begin{abstract}
This paper investigates assessment on the challenges and prospects of entrepreneurial attitude on students in the case of Wachemo University Ethiopia. The study used survey by method using a structured questionnaire which was administered to 350 sample respondents. In order to accomplish the objectives of the study, independent variables such as gender of students, family occupation, specialization of students, parent's support to selfemployment and socio cultural factors that influence student's attitude and the dependent variable, entrepreneurship attitude was discussed. Data was analyzed by using descriptive statistics like tables and graphs. Also multiple linear regression models were used to examine the variation in the entrepreneurship attitude related to the variation in each of the independent variables of the study. Those findings suggest that entrepreneurship education is strong enough to encourage student to establish a new business, but it can make students feel that establishing a business is worthwhile. Based on findings, Universities should establish a business center where youth can have a practical experience to enrich their entrepreneurial involvement thereby changing their attitude towards entrepreneurship programs.
\end{abstract}

Keywords: Entrepreneurship, Attitude

DOI: $10.7176 / \mathrm{EJBM} / 13-19-01$

Publication date:October $31^{\text {st }} 2021$

\section{Introduction}

Entrepreneurship has emerged as the most powerful economic force the world has ever experienced. The entrepreneurial interest has acquired its intensive level almost everywhere in the world. The developed economics consider it as a realizing socio-economic agent and crucial for technological progress, product and market innovation. At most of the developing countries, it is seen as an engine of economic progress, job creation and social adjustment (Barringer, 2008). An attitude is a tendency to act or react in a certain manner when confronted with certain stimuli. Here stimuli may be object, individual, idea or anything else that an individual can react negatively or positively to it. The reaction may take verbal, physical, mental or behavioral form attitude as emotional trends in response to affairs, persons, locations, events or ideas people are motivated to use systematic processing when they want to achieve a desired level of confidence in their judgments (Wendy, 2000).

According to Ibid (2008), they have a high tend ability and awareness for recognizing and exploiting business opportunities. Entrepreneurs mainly depend on potential for entrepreneurship that requires potential entrepreneurs. The entrepreneurial potential of have emerged as a front line national agenda item and succeeded to attract the interest of policy makers, scholars and development agencies all over the world.

Moreover according to Barrier (2007), development is more than every linked to entrepreneurship. Institutions and individuals promoting development now see entrepreneurship as a strategic development intervention that could accelerate the development process. Furthermore, institution and individuals seem to agree on the urgent need to promote entrepreneurship. Development agencies see entrepreneurship as an enormous employment potential, Politian; see it as the key strategy to prevent urgent needs; farmers see it as an instrument for improving farm earning; Women see it as employment possibility near to their home, which provide autonomy, independence and reduced need for social support.

As stated in work of Barrier (2007) even though the new education policies of Ethiopia are inclined towards entrepreneurship education, there was still implementation problem that seems to exist and entrepreneurial thinking is lacking from Ethiopia youth. Therefore, this study intended to access student's attitudes towards entrepreneurship.

\section{Statement of the problem}

The current trends in terms of global economic recession have generated a number of economic and social problems especially for the developing and underdeveloped nations. Almost everywhere in the world, universities are trying to focus on entrepreneurship not list, because future pool of the entrepreneurs consists of university students (potentially entrepreneurs). Academic researchers have begun to explore the entrepreneurship 
attitude of potential of entrepreneurs (Hailay, 2007). According to him, entrepreneurial attitude could predict entrepreneurial interest, which in turn related to entrepreneurial career development in the potential entrepreneurs. Particularly in Ethiopia the present socioeconomic indicators have shown the existence of high demand for promotion entrepreneurial actives in the country. In attempt to address the problem of an employment and to promote economic development, our government decides to adopt entrepreneurship as a solution. However, majority of the students in the Ethiopia seeking jobs from the government and have high attitude and intentions toward government gobs, this is due to the fact that students low belief and attitudes in toward new venture creation and the entrepreneur. That is why; the researchers believed that the presence of entrepreneurial attitude among university students may be important indicators of the pool of potential entrepreneurs. Therefore, this study wills tray to create awareness to students towards entrepreneurship by targeting graduating class students at Wachamo University Ethiopia. Previous studies show that the problem of entrepreneurial attitude and business orientation of students are not solved yet. Because of these facts, this study was tried to pick out the factors that encounter them to do so.

\section{Objective of the study}

The main objective of the study is to assess of challenges and prospects of entrepreneurial attitude on students.

\section{Review of related literature}

The word entrepreneur originates from the French word "Entitreprendre" which means" to undertake" or "go between" In business context, it implies to start a business. Entrepreneur is one who originates, manages and assumes the risk of a business or enterprises. The concept entrepreneur has a wide range of meaning, on one extreme and entrepreneur is a person of very high attitude who pioneers changes, possessing characteristics found in any small fractions of the population. On the other way it means anyone who wants to work for him or she is considered to be an entrepreneur (David Mc Cleland, 1981). According to Barrier (2008) there are two primary reasons that peoples become entrepreneurs and start own firm. Namely, to be there boss, pursue their own idea, the rewards of starting way of life realize financial rewards. Hailey (2003) found that the intention to become an entrepreneur money depend on personal attraction toward entrepreneurship, perceived social norms and perceived feasibility (self-efficiency).

Ajzen (1991) indicated that resources, opportunity and support available to perform a behavior influences entrepreneurial intention. Decides, subjective norms, the perceived social pressure to perform or not to perform the behavior, affect a startup of some sort of business.

There are so general agreements that entrepreneurship education is, must be rather than shall be. It is described perhaps the most important economic development mechanisms. To succeed in this entrepreneurship education must be concerned with learning and facilitating for entrepreneurship no about it "Doing" is more than "thinking" knowledge has to be converted in to solutions that benefits customers in the market place (Formiea, 2002). The existed empirical research findings that support and gave evidence that entrepreneurship education influence student's intention to become entrepreneurial. According to Mekkonen (2010) in his research findings, revealed that taken entrepreneurship education course has positive effects on entrepreneurial career choice of students and the effects are significant.

Dyer (1994) found link between offering entrepreneurship education course and students intention to start business. The further explained that entrepreneurship education training might be some students the confidence they need to start their own business. Robbenens et al (1991) found that entrepreneurship education increase and improve the perceived feasibility for entrepreneurship by increasing the knowledge of students, building confidence and promote self-efficacy.

Ajzen(1991)indicated that resources, opportunity and support available to perform a behavior influences entrepreneurial intention. Decides, subjective norms, the perceived social pressure to perform or not to perform the behavior, affect a start up of some sort of business (Ajzen, 2005). The existed empirical research findings that support and gave evidence that entrepreneurship education influence student's intention to become entrepreneurial. According to Kekkonen (2010) in his research findings, revealed that taken entrepreneurship education course has positive effects on entrepreneurial career choice of students and the effects are significant. Dyer (1994) found link between offering entrepreneurship education course and students intention to start business. The further explained that entrepreneurship education training might be some students the confidence they need to start their own business. Robbenens et al (1991) found that entrepreneurship education increase and improve the perceived feasibility for entrepreneurship by increasing the knowledge of students, building confidence and promote self-efficacy. According to them, it also improve the perceived desirability for entrepreneurship education is highly desirable regarded and socially acceptable and that it can be rewarding. According to Bird (1988) Intentionality as the state of mind directing a person's attention towards a specific goal in order to achieve something. Entrepreneurial intentions are directed towards creating an entrepreneurship and creating new values in an existing venture. Entrepreneurial is an outcome of entrepreneurial intention so that it is 
typical of emerging business. According to Davidson,(1995) entrepreneurial intentions are assumed to predict individual choices to form their own firm.

The major sources of wealth and development for human being are land, manpower, capital and entrepreneurship. The first three can be easily seen, measured and acknowledge. Entrepreneurship, however, is something that cannot be easily identified, measured and recognized. There is no consensus in defining the word entrepreneurship.

There are so general agreements that entrepreneurship education is, must be rather than shall be. It is described perhaps the most important economic development mechanisms. To succeed in this entrepreneurship education must be concerned with learning and facilitating for entrepreneurship no about it "Doing" is more than "thinking" knowledge has to be converted in to solutions that benefits customers in the market place. (Formiea 2002: P.171)

Several studies evidenced that great relationship exist between entrepreneurial intention and entrepreneurship. According to Bird (1988), Intentionality as the state of mind directing a person's attention towards a specific goal in order to achieve something. Entrepreneurial intentions are directed towards creating an entrepreneurship and creating new values in an existing venture. Entrepreneurial is an outcome of entrepreneurial intention so that it is typical of emerging business. According to Davidson,(1995) entrepreneurial intentions are assumed to predict individual choices to form their own firm.

It is not true that successful entrepreneurs are born that way; in fact any one can be successful entrepreneur. However, there are some specific entrepreneurial trials a person must have to be successful in the field of business courses entrepreneurship is not for everyone. The essential entrepreneurial attitudes are independent persistence and determinant, self-confidence, creativity and organized goal oriented (Hailay, 2007).

Entrepreneur normally defined as risk taker in new venture creation are un equal optimistic hard driving committed in individual who drive great satisfaction from being independent starting a new business require more than just an in idea requires a special person, an entrepreneurial who combines sound judgment planning with risk staking to insure success of his her business (Micheal H, 2008).

According to Barrier, (2008), there are two primary reasons that peoples become entrepreneurs and start own firm. Namely, to be there boss, pursue their own idea, the rewards of starting way of life realize financial rewards and discussed as follows.

Pursue their own idea; this reason describes people's start their own business is to pursue their own ideas, some peoples are naturally alert and when they recognize idea for these ideas, realized. Because of their passion and commitments, some employs choose to have the means to develop their own business as a means to develop their own idea (Ibid 2003).

Set explicit innovation goals, need to mutually agree on by the employee and management, so that specific stapes can be achieved. Create system of feedback and positivity enforcements. This necessary for potential renovators or create of ideas to realize the acceptance and rewards exit. Emphasis individual, responsibility, confidence, trust, and accountability are the key futures in the success of any innovative program. Provide rewards for innovative idea. Reward system should enhance and encourage others to risk and achievements (Hailay,2007).

\section{Conceptual Framework}

Based on the above review of related literature this study follows the conceptual framework for the study entitled assessment of challenges and prospects of entrepreneurial attitude on students

Independent variables

Dependent variable

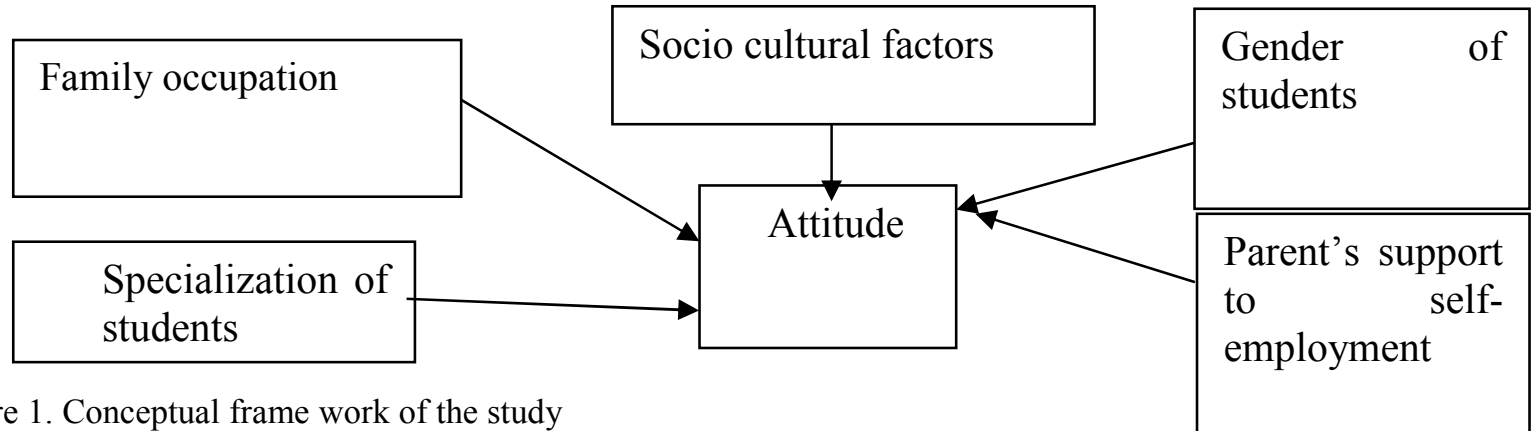

Figure 1. Conceptual frame work of the study

\section{Research methodology}

The research design a study was used is descriptive design because the main purpose of descriptive research is to describe the state of affairs, as it exists at the present time. Both primary and secondary source of data was used to gather pertinent information on the issue under the study. Primary data was gathered from Wachemo 
University students through structured questionnaire. Secondary sources of data for this research was books, annual organizational reports and documents, internet sources, and other relevant unpublished materials related to the topic under the investigation. The population for this study was comprised of all students of Wachemo University students. The total number of students, who graduated in $2011 \mathrm{EC}$, is 2820 . The study considers 350 students as a sample to undertake the study. The researcher employed stratified sampling technique by grouping into six College; Agricultural science, Business and Economics, Natural and computational science, Medicine and health science, Engineering and Technology and Other social science and Humanities. To get the determined sample size, the study was taken the sample proportionally based on their number of students of each College. The study was used a simplified formula provided by Yamane (1967) to determine the required sample size at $95 \%$ confidence level and with 5\% level of precision. A survey method of data collection through questionnaire was used to collect data for this study. After pre-testing, the structured survey questionnaire was administered on a total of 350 students. Quantitative analysis techniques was employed to show processed data in absolute terms through the use of descriptive statistical tools such as frequency, valid percentages, mean and standard deviation of results with the help of SPSS version 20 by employing descriptive and inferential analysis techniques. In this paper the model are expressed using 5-point Likert scale from strongly agree to strongly disagree Before being administered, the questionnaire was subjected to reliability and validity testing. Using the Cronbach Alpha test, the questionnaire was tested for internal consistency reliability. To know about the attitudes of students towards entrepreneurship, multiple regressions using the following model can predict: The value of a dependent variable is defined as a linear combination of the independent variables plus an error term

A questionnaire was pre tested on some respondents to make the data collecting instruments objective, relevant, suitable to the problem and reliable. Moreover, to have valid conclusion, inferential statistical model was used to test the relationship between variables. Cronbachs alpha is a reliability coefficient that indicates how well the items in a set are positively related to one another it is computed in terms of the average inters correlations among the items. On this study to increase the level of alpha the researcher tried to use data reduction by using SPSS software so for all variables Cronbach's alpha is greater than 0.7.

\section{Result and Discussion}

Generally 350 questionnaires were distributed to students. Out of which 300 were completed and returned successfully. Finally, conclusion and recommendation was made based on the findings.

Table 1. Demographic Profile of Respondents

\begin{tabular}{|c|c|c|}
\hline Gender & Number & Percentage \\
\hline Male & 149 & 49.7 \\
\hline Female & 151 & 50.3 \\
\hline Total & 300 & 100 \\
\hline \multicolumn{3}{|l|}{ Marital status } \\
\hline Married & 263 & 87.7 \\
\hline Unmarried & 37 & 12.3 \\
\hline Total & 300 & 100 \\
\hline \multicolumn{3}{|l|}{ Age } \\
\hline $17-19$ & 46 & 15.3 \\
\hline $20-22$ & 171 & 57 \\
\hline $23-25$ & 83 & 27.7 \\
\hline Total & 300 & 100 \\
\hline \multicolumn{3}{|l|}{ Department } \\
\hline Business & 88 & 29.3 \\
\hline Non-business & 212 & 70.7 \\
\hline Total & 300 & 100 \\
\hline \multicolumn{3}{|c|}{ Family occupation } \\
\hline Businessman & 58 & 29.3 \\
\hline Farmer & 139 & 46.3 \\
\hline Civil servant & 103 & 34.3 \\
\hline Total & 300 & 100 \\
\hline
\end{tabular}

Source: Own survey 2020

As it is depicted in table 1, majority of the respondents or $151(50.3 \%)$ of the enterprise owners or managers are males and the remaining $149(49.7 \%)$ are females. The other demographic variable is marital status of the respondents, from those all students $263(87.7 \%)$ of them are unmarried and the remaining $37(12.3 \%)$ of them are married. From this we can understand that most of the students are unmarried. The sample response shows that $171(57 \%)$ of the respondents are in age range between $20-22$ followed by $83(27.7 \%)$ of the respondents whose their age range between $23-25$, also $46(15.3 \%)$ of the respondents are within the age range 17-19, From the 
above information we have seen that most of the respondents are 20-22 age range. The above table shows that 88 $(29.3 \%)$ of the students are business education learners and the remaining $212(70.7 \%)$ of them are non-business students. The sample response shows that 139(46.3\%) of the respondents family were business owners, $103(34.3 \%)$ of the respondents family were farmers and the remaining $58(29.3 \%)$ of the respondents family was business were Civil servant.

ANOVA Test Result

ANOVA ${ }^{\mathrm{a}}$

\begin{tabular}{|ll|l|l|l|l|l|}
\hline Model & & Sum of Squares & df & Mean Square & F & Sig. \\
\hline \multirow{2}{*}{1} & Regression & 8.153 & 5 & 1.631 & 7.800 & $.000^{\mathrm{b}}$ \\
& Residual & 61.455 & 294 & .209 & & \\
& Total & 69.607 & 299 & & & \\
\hline
\end{tabular}

a. Dependent Variable: ATTITUDE

b. Predictors: (Constant), EFFEC PARENTS, SOCIO ECONO, gender, EFFECT OF EDU, BUSINESS

The ANOVA result in the above table shows that there is linear relationship between dependent variable (Students attitude) and the set of independent variables. This means the model is adequate in explaining the relationship between independent and dependent variables. This is because overall $\mathrm{P}$ value of the model $(\mathrm{p}=$ $0.000<0.01$ ) shows the model is adequate at $1 \%$ level of significance.

Results of Multiple Regression Analysis

Table 2. Results of Multiple Regression Analysis

\begin{tabular}{|c|c|c|c|c|c|c|}
\hline \multirow[t]{2}{*}{ Model } & & \multicolumn{2}{|c|}{$\begin{array}{l}\text { Unstandardized } \\
\text { Coefficients }\end{array}$} & \multirow{2}{*}{\begin{tabular}{|l} 
Standardized \\
Coefficients \\
Beta \\
\end{tabular}} & \multirow[t]{2}{*}{$t$} & \multirow[t]{2}{*}{$\begin{array}{l}\text { P- } \\
\text { Value }\end{array}$} \\
\hline & & B & Std. Error & & & \\
\hline (Constant) & & 2.313 & .306 & & 7.569 & .000 \\
\hline Gender & & .065 & .053 & .067 & 1.219 & .224 \\
\hline Family occupation & & .063 & .055 & .064 & -1.149 & .0025 \\
\hline Socio economic & & .217 & .046 & .258 & 4.698 & .000 \\
\hline Specialization & & 138 & .051 & 150 & 2.712 & .007 \\
\hline Parents support & & .102 & .056 & .102 & -1.834 & .0068 \\
\hline $\mathrm{R}^{2}$ ( $\mathrm{R}^{2}$ adj. $)$ & $0.660(0.636)$ & $0.78(0.75)$ & & & & \\
\hline
\end{tabular}

a. Dependent Variable: attitude

As shown in table, the coefficients of the regression $(0.065, \mathrm{p}>0.01)$

For socio-demographic factor, gender is not significant at 1 percent and 5 percent level of significance and it is concluded there is no dependable pattern of relationship between gender on entrepreneurial attitude of students

The other factor family occupation $(0.067, \mathrm{p}<0.01)$ is significant determinant factor to the entrepreneurial attitude of students. Students whose their family occupation is business are $.063 \%$ greater than students with family occupation is non-business on entrepreneurial attitude.

The regression output shows that Socio economic factors $(0.217, \mathrm{p}<0.01)$, has a significant relationship with entrepreneurial attitude of students. This clearly shows that when the Socio economic factors increases by one the entrepreneurial attitude ill increase by 0.217 .

The result additionally exhibited that the other factor influencing the entrepreneurial attitude is field of specialization $(0.138, \mathrm{p}<0.01)$, the regression result clearly shows that there is significant and positive relationship with the entrepreneurial attitude of students. The result of regression helps to accept the null hypothesis which states that there is significant relationship on the entrepreneurial attitude students in relation to the difference in field of specialization of students. This shows that enterprises leaded by plan has more perform than which do not leaded by plan.

Other variable in this study is parents support $(0.102, \mathrm{p}<0.01)$, as shown in the regression output it has positive and significant relationship with the entrepreneurial attitude of students. Also the hypothesis states that there is significant relationship on the entrepreneurial attitude students in relation to the difference in family support so this hypothesis is supported. This may indicate students who get entrepreneurship support has better motivation for entrepreneurship.

\section{CONCLUSION}

Based on the findings above, there are some of conclusions that can be given. The attitude of students towards entrepreneurial activities are positive and starting a business, launching a new product or venture, or becoming 
an entrepreneur, working for them self is very appealing to them and they have idea of starting their own business and many of the respondents show willingness to engage in entrepreneurship activities after completing their school study. Challenges that influence student's attitude towards entrepreneurship are lack of entrepreneurship knowledge and skills, lack of access to finance-capital to invest, lack of information to start a business, lack of interest in entrepreneurship, social/cultural attitude towards (youth) entrepreneurship high risk of conducting business and others. This study found that entrepreneurship education positively effects students' knowledge about entrepreneurship and their self-efficacy; the self confidence in skills and competences that they can engage in entrepreneurship successfully. Regarding future plans upon graduation, students changed their thinking about creating their own business after the end of the program. The high quality of education in innovative fields provides a great opportunity for the establishment of new entrepreneurship. Through entrepreneurship education, young people, learn organizational skills, including time management, leadership development and interpersonal skills. To become a successful entrepreneur, it is desirable that students go through both specialized entrepreneurship education and diverse educational experiences. This increases the student's chances of creating entrepreneurial ventures and raising his/her personal wealth. Those findings suggest that entrepreneurship education is strong enough to encourage student to establish a new business, but it can make students feel that establishing a business is worthwhile. Self-employed parents act as a positive role model and knowledge transferors to their children, increasing their entrepreneurial intention students whose parents are self-employed, have a better attitude toward the founding of a new company. The students of entrepreneurs may have inherited or learned risk-tolerance and entrepreneurial skills from their parents that increase their probability of choosing a career in entrepreneurship and the effect of self-employed adoptive parents. Student with family background is playing an important role in order to improve their intention to establish a business Area of specialization has influence on the attitude of students towards entrepreneurship However, majority of the respondents seeking job from the government and have high attitudes and intention towards government's job. This is due to the fact that students low beliefs and attitudes towards new venture creation and the entrepreneur.

\section{REFERENCES}

Ajzen, I. \&. (2005). The Influence of Attitudes on Behavior. In D. Albarracín, B. T. Johnson, \& M. P. Zanna (Eds.). The handbook of attitudes ., (pp. 173-221).

Barringer. ((2008)). Entrepreneurship: Successfully Launching New Ventures. 2nd Editio.

Barrier.. ( (2008)). Entrepreneurship successfully launching,. new edition,: personal parent hall.

Cleland, D. M. ( (1981)). Entrepreneurship placed an emphasis on innovations.

Dyer, W. G. ((1994).). Potential contributions of organizational behavior to the study of family owned businesses. Family Business Review.

Ajzen, I. \&. (2005). The Influence of Attitudes on Behavior. In D. Albarracín, B. T. Johnson, \& M. P. Zanna (Eds.). The handbook of attitudes ., (pp. 173-221).

Barringer. ((2008)). Entrepreneurship: Successfully Launching New Ventures. 2nd Editio.

Barrrier.. ( (2008)). Entrepreneurship successfully launching,. new edition,: personal parent hall.

Cleland, D. M. ( (1981)). Entrepreneurship placed an emphasis on innovations.

Dyer, W. G. ((1994).). Potential contributions of organizational behavior to the study of family owned businesses. Family Business Review.

G.), B. ( (1988). An Analysis of Drawings on the International Monetary Fund by Developing CountriesManaging Global Money. London.: Palgrave Macmillan, .

Hailay G/Tinnsa Beyene. ((2003)). Entrepreneurship and small business management. Mekelle: Mekelle University.

Michael H.Morris \& DannelF. Kutafor. First edition, . ( (2008)). India by akash pres.

Yamane, T. (.1967.). Statisti cs,AnIntroductoryAnalysis, 2nd Ed., . New York: : Harper and Row. 